\title{
The Extension of French Welfare to Overseas Departements
}

\section{Thierry Michalon}

\section{(2) OpenEdition}

\section{Journals}

Édition électronique

URL : http://journals.openedition.org/plc/258

DOI : $10.4000 /$ plc. 258

ISSN : 2117-5209

Éditeur

L'Harmattan

Édition imprimée

Date de publication : 14 janvier 2004

Pagination : 109-125

ISBN : 2-7475-7061-4

ISSN : 1279-8657

Référence électronique

Thierry Michalon, «The Extension of French Welfare to Overseas Departements », Pouvoirs dans la Caraïbe [En ligne], 14 | 2004, mis en ligne le 02 mars 2011, consulté le 19 avril 2019. URL : http:// journals.openedition.org/plc/258; DOI : 10.4000/plc.258 


\title{
The EXTENSION OF French WeLfare to OVERSEAS DEPARTEMENTS
}

\author{
par Thierry MICHALON \\ Maître de conférences en droit public \\ Membre du CRPLC \\ Université des Antilles et de la Guyane
}

At the end of World War II, the four oldest colonies of France (Guadeloupe and Martinique in the Caribbean, Guyane on the northern border of Brazil, Réunion in the Indian Ocean, close to Madagascar) obtained the status of départements they had been claiming for a long time. A statute adopted by French Parliament on April 19, 1946, put an end, as far as they were concerned, to their colonial legal status.

Colonies were not ruled by common statutes and decrees, but only by specific provisions enacted by the Government and not by Parliament. Several members of Parliament elected in these old colonies took advantage of the heavy radical majority ruling France at the end of World War II. They urged Government to carry out the decolonization of their territories not by means of secession but by the opposite method: by integrating them into the field of enforcement of common rules of law, enacted for people living in those main French administrative districts called départements, in other words for people regarded as representing the French nation itself...

Then started, therefore, a process of extension of French laws to these new départements. Among these laws are "social" laws, setting up one of the most comprehensive welfare systems in Europe, which is nowadays enforced in French islands in the Caribbean.

Part I of this paper will give an overview of French welfare system. Part II will sum up the main stages of its extension to overseas départements. 


\section{FRENCH WELFARE SYSTEM: AN OVERVIEW}

The French welfare system never was designed as a whole. The current system is the outcome of a long series of provisions adopted since the second half of the $19^{\text {th }}$ century.

However the end of World War II boosted the setting up of a more coherent structure. On early 1945, the political platform of the Conseil national de la Résistance - an advisory board working along with Général de Gaulle in Algiers and then in Paris - included a claim for "a comprehensive social security project aiming to give all citizens some means of living whenever they are unable to get them through work". So the October 4, 1945 Ordinance put together the multiple social insurance systems and institutions that had been set up all along the years. But it rapidly turned out to be impossible to achieve a unified system, as professional categories that used to have a social insurance system before 1945 wanted to keep it. Today's France therefore has, on one hand, a Main System - the Régime général - on the other hand a lot of Special Systems - the Régimes spéciaux - designed for farmers, for instance, or independent professions. We will give a look here to the Main System only.

\section{MAIN SYSTEM'S FEATURES}

The French welfare system is not based upon State intervention, but upon a social insurance basis: contributions and benefits are partially proportional to income, up to a ceiling. Above that ceiling, people may use "free" protection, by paying extra contributions to other insurance institutions, freely competing on the market. Financing is a matter for the people concerned only, and for their employers: French State is only checking the correct operation of the system, as it is regarding it as a public service.

Unlike the British system, the French system is preserving a private, liberal medical system. Everyone remains free to be treated by 
the physician he chooses: he has to pay his fees, then to buy medicines. He will afterwards be partially refunded.

The Main System is operated by offices at three levels: Primary Offices, Regional Offices, and National Office. Besides, we have Family Allowances Offices, run by representatives of employees, employers, and the self-employed, collecting their own contributions and paying allowances to workers in commerce and industry, as to the selfemployed.

Three large national offices are managing the whole system:

- the National Office for Employees Sickness Insurance, heading Primary Offices and Regional Offices, dealing with sickness, pregnancies, disability, death, industrial accidents, professional diseases;

- the National Office for Employees Old Age, dealing with old age only;

- and the National Office for Family Allowances, heading Family Allowances Offices in every départements.

These offices are run by including an equal representation of both employers and employees: $50 \%$ representatives of trade unions, $50 \%$ representatives of employers, and some Government-appointed "skilled personalities". Supervision boards, including members of Parliament, are checking the operation of the joint employers and employees' boards. Since a 1996 reform, an annual Social Security Finance Bill is discussed and adopted by Parliament: thus Parliament has to approve the main lines of health and social policy and to plan the income of every basic compulsory social insurance system.

Unemployment Insurance is not included in the main social security system. As late as 1958 was set up "social partners" - i.e. representatives of trade unions and employers - an unemployment insurance system run by private local joint associations called ASSEDIC (Associations for Employment in Industry and Commerce) and by a national office named UNEDIC (National Union for Employment in Industry and Commerce). Collecting compulsory contributions from both 
employers $\left(4 / 5^{\text {th }}\right)$ and wage earners $\left(1 / 5^{\text {th }}\right)$, these offices have to pay to unemployed people a part of their previous income.

As far as social assistance is concerned, it appears as being split into a lot of benefits, most of them being run by each département: child care, health care, old people care, disabled care, housing care, and social reintegration care. In 1988 however, a nation-wide minimum integration income (RMI) was set up: State Administration pays an allowance, as professional integration falls within the province of départements.

\section{MAIN SYSTEM'S ALLOWANCES}

They are paid to all employees, and split into three categories:

- social insurances;

- industrial accidents (and professional diseases);

- and family benefits.

\section{Social insurances}

- Sickness insurance: partially refunding physicians fees, medicines, and hospital, and partially substituting for professional wage;

- Pregnancy insurance: totally refunding pre and post-birth compulsory medical examinations, and substituting for loss of wages for a 16-week leave;

- Disability insurance: partially compensating income loss for non-professional sickness, non-professional accident or early body weakening;

- Death insurance: paying to the family a death benefit of 3month wages;

- Old age insurance: paying to retired workers a pension paid by working employees, not by capitalization of contributions made by the recipient all along his professional life; retiring may occur at 60 , with full pension - i.e. $50 \%$ of the average earning of the seventeen best years - if one has been contributing for forty years;

- Widowhood insurance: paying to the widow - or widower - a 2-year (or 5-year, if more than 50) benefit. 


\section{Industrial accidents and professional diseases}

The Main System covers any accident occurring on the job to anyone working for one or several employers, as well as accidents occurring on the way from home to work or back. As far as professional diseases are concerned, there is a list of about 300 such diseases, but diseases not included in that list may be qualified as "professional". Primary Offices are taking care of all medical expenses, and paying a substitute income.

\section{Family benefits}

There are more than twenty types of family benefits, aiming at improving the standard of life of anyone, living in France, either earning a wage or not, having one or several children to take care of.

- Family benefits: core of the systems, they are paid to anyone at least two children to take care of, regardless of personal income;

- Childhood care: includes three types of allowances, i.e. allowance for new-children (a 9-month monthly allowance), allowance for employment of a maternal assistant to take care of a child up to 6 years old, allowance for giving a child (up to 6 years old) to a nurse taking care of him in his own house;

- Large families care: includes two types of allowances: allowance for parental education, paid for three years to the parent who stops working so as to take care of a newborn child, and family complement, in addition to family benefits for families including a least three children, whose income stands below a given amount;

- One-parent families care: includes two types of allowances: allowance for "isolated parent" - paid to parents living alone -, allowance for family support - paid to anyone living alone and taking care of an orphan or a neglected child-;

- Housing care: includes three types of allowances: allowance for family-size housing, designed to help to pay 
the rent of the installments if children and low income; loans for the improvement of housing (low level: $7000 \mathrm{~F}$ at most, but low cost: $1 \%$ interest); allowance for a family moving to a larger place to accommodate a third child ore more;

- Assistance to families with school-age children: includes two types of allowances: allowance at the beginning of the school year (with income condition, for any children from 6 to 18), and scholarships for high school;

- Assistance to disabled children: includes two types of allowances: allowance for special education, paid to parents of a disabled child, with income condition, and complement to that allowance if the child requires help from a non-member of the family or heavy expenses.

\section{MAIN SYSTEM'S FINANCING} resources:

French welfare general system is financed by four types of

- Contributions from any income paid as a counterpart of a job; for instance, contributions for sickness insurance is today $12,8 \%$ (on the whole salary) paid by the employer and $0,75 \%$ paid by the employee;

- Some taxes: on alcoholic beverages, on pharmaceutical advertisements, on automobile insurance, for instance;

- A special tax set up in 1991, the General Social Contribution (Contribution sociale généralisée): 7,5\% of any income - not merely on wages;

- A special tax set up in 1996, the Contribution for Settlement of Social Debt (Contribution au règlement de la dette sociale): 0,5\% of any income, until 2012.

Therefore the average amount of welfare contributions paid on wages in France is heavy: about $55 \%$ of the net income, $28,1 \%$ on the gross wage. Wages cost is therefore high... but income tax rather light. Government policy since 1991 (setting up of the General Social 
Contribution) is trying to shift welfare financing from contributions paid on wages to taxes.

\section{UNEMPLOYMENT COMPENSATION}

Unemployment Insurance was not set up in 1945 along withy the Main System, but by an inter-professional agreement signed in 1958 . Unemployment insurance is operated by private associations, ASSEDIC (Association for Employment in Industry and Commerce) on a local level, UNEDIC (National Union for Employment in Industry and Commerce), whose boards include an equal number of representatives of employees and employers. A state agency, the National Agency for Employment (ANPE), is in charge of helping jobless people to find new jobs. Checking job-seekers getting unemployment allowance is done by the Ministry of Labor. Thus three types of institutions are dealing with unemployment.

Unemployment allowances are paid to wage-owners who lost their job (who did not resign), who have been paying contributions to Unemployment Insurance for a given span of time, who are physically fit for working, who registered with the ANPE and actually are looking for a new job. They get a substitute income that is split into two allowances:

- A main allowance is paid for a time related with the time the beneficiary gas contributed to Unemployment Insurance and with his age; its amount is related to the amount of the wages he got during his last year at work, but it slides down as time runs;

- A training allowance, to help job-seekers improve their professional skill.

A solidarity system is completing unemployment allowances, so as to take in charge for some time job-seekers who are not eligible to unemployment insurance due to their poor working experience, or who went through with their rights to allowance. These job-seekers may thus get other allowances:

- One-year integration allowance, for released prisoners, refugees, stateless people, asylum-seekers, and so on; 
- Specific solidarity allowance for long-term unemployed when they are through with their rights to insurance allowance;

- Specific waiting allowance; enables an unemployed worker who is getting the Minimum Integration Income (Revenu minimum d'insertion) or the specific solidarity allowance to wait until he may retire.

\section{THE LEGAL MINIMUM WAGE}

In 1950 was created the National Inter-professional Guaranteed Minimum Wage (SMIG), which was transformed into a Minimum Growth Wage (SMIC) in 1970. It's present amount is 7,19 euros/hour, i.e. 1.090 euros/month for 35 hours a week. Welfare contributions are then deducted.

\section{THE MINIMUM INTEGRATION INCOME}

In 1988 was set up the Minimum Integration Income (RMI). This allowance is worth 389 euros/month for one person at home, 583 euros for two persons, 700 euros for three persons, and 817 euros for four persons. It may be granted by the Préfet (Government-appointed head of the département) to anyone who is at least 25 and has been living in France for at least three years. This allowance has been so far financed by the State, but may soon be financed by the département's council. As a counterpart, the beneficiary has to sign an "integration contract" with the Integration Local Commission, where representatives of the Government and members of the council of the département are sitting. About one million people in France are getting this Minimum Integration Income.

\section{THE EXTENSION TO OVERSEAS DEPARTEMENTS}

As early as 1833, Guadeloupe, Guyane, Martinique and Réunion were entitled to a specific legal treatment from Paris, due to the important part they played within the French colonial empire. An April 24, 1833 statute set up in each of these colonies a Colonial Council, chosen by an 
electorate paying a minimum amount of tax, i.e. made up of property owners. The council was granted the right to adopt in some matters "colonial decrees" to be then accepted or rejected by the king; other colonies were directly ruled by king's ordinances. A May 3, 1854 statute laying down the basis of colonies' legal status ruled out any intervention of the Parliament for them, so that they would be ruled by decrees only; but Guadeloupe, Martinique and Réunion were to be ruled by statutes in some specific matters such as political rights, civil law, criminal law, commercial law. Moreover, each of these three colonies were given a partially elected assembly called Conseil général, i.e. the same name used for the elected assemblies of départements; a 1870 decree changed their mode of election to universal suffrage, as in France itself; and several provisions of the 1871 statute on Conseils généraux were to be applied to them. Most of all, these old colonies alone - since the 1870's have elected representatives to both houses of the Parliament. And the 1932 statute setting up Family Allowances in mainland France was extended to Guadeloupe, Martinique and Réunion by a 1938 decree.

\section{DISAPPOINTED EXPECTATIONS}

As we can see, there was an obvious political will to deal with old colonies as if they were closer to the French nation than other colonies...

No wonder then that some representatives of these countries in Parliament - mostly members of the Communist Party - introduced a bill in early 1946 to change them into départements: they solemnly stated that such an "integration" would be the mere "outcome of an historical process". However, as one of them, Aimé Césaire from Martinique put it later: "We were thinking: in France, there are a lot of very sophisticated welfare laws, but we have nothing of the sort. We become French départements, and, all of a sudden, all welfare laws that Frenchmen have been fighting for for fifty years are enforced here!"

This actually took some time.

A two-year union and political struggle was necessary to get the Allowance to Retired Workers to be extended to the new "overseas départements", through a March 30, 1948 decree. 
On June 1, 1949, the Universal Social Security Office was opened in Martinique, dealing with the whole welfare system, as manpower then was still shifting from one job to another several times a year.

On January 1, 1952, the Professional Accidents Insurance System was set up.

An August 13, 1954 statute extended Social Insurances to the overseas départements, seven years late, therefore.

As a matter of fact, although March 19, 1946 statute was requiring that all new statutes and decrees should be automatically enforced in the départements d'outre-mer - according to an assimilationist pattern - French governments rapidly shifted to an adaptation policy -according to section 73 of the October 27, 1946 Constitution - and no laws were then extended without a careful study of their economical and social impact on a local level. So many of them were adapted, or non-extended, in the 1950's and the 1960's, partly because of the particular demographical situation of overseas départements: the point here was not to encourage demographic expansion, as in mainland France at the end of World War II, but to cut it down, as the birth rate was still very high. Such was the thinking behind the July 31, 1963 statute which set up the principle of overall social parity: people in overseas départements were to pay the same contributions to family benefits as in mainland France, but they were to receive directly a part only of the allowances, the remaining part being paid as collective subsidies. Actually, that statute was setting up in every overseas département a Compulsory Health and Social Action Fund (FASSO) which was to get about one half of the overall amount of family allowances, and using them for collective services such as school canteens, birth control centers, vocational training centers, and so on.

Until 1980, there was no unemployment allowance system in overseas départements, but only a fund affected to "development working sites" managed by the Préfet.

In the early 1980's, welfare was still rather restricted in these départements: in 1982, benefits paid in Martinique were worth $8.581 \mathrm{~F}$ 
per capita, as opposed to $17.211 \mathrm{~F}$ in continental France. In 1984, the legal minimum wage in Guadeloupe, Guyane and Martinique was 16,7\% below continental France's.

However, several nation-wide provisions adopted in 1975 were immediately enforced in overseas départements: this was the beginning of a new policy aiming at extending social security and family benefits to social groups that were not yet protected, and that policy became stronger from 1986 on. Nevertheless, a January 20, 1989 decree laid down the conditions of implementation of the Minimum Integration Income in overseas départements:

- allowance was to be $20 \%$ lower than in continental France, as the legal minimum wage was itself $20 \%$ lower;

- these $20 \%$ were to be paid by the State to départements, to help them financing professional integration actions;

- Minimum Integration Income was to be less generous still to farmers.

\section{THE IMPACT OF "RIPERT REPORT"}

In 1989 a thorough survey of welfare in these départements was conducted by a Commission on Social Equality and Economic Development in overseas départements, headed by Mr. Jean Ripert. Released in January 1990, the Ripert report pointed out the gap between welfare overseas and welfare in mainland France:

- family benefits for a second child and more, allowance for "isolated parent", allowance to families moving to larger places, family income complement, and allowance for family support, were paid with lower amounts;

- rights to get housing allowances, family complement, and special education allowance, were not as widely open as in continental France; 
- childhood care, allowance for parental education, and allowance for giving a child to a nurse at her home had not been extended;

- but: family benefits for the first child, and allowances for the protection of motherhood were paid in overseas départements only.

The Ripert report included then fifty-eight recommendations aiming at shedding social parity in favor of social equality with continental France in a 6-year span of time: that was to say that allowances should be paid to beneficiaries the same way, and with the same amounts, as they are to beneficiaries in mainland France. Although social parity was based upon actual social and cultural specificities in overseas départements - such as a higher birth rate - it was regarded here as discriminatory and humiliating. Several reforms were carried out so as to implement suggestions made by the Ripert's commission:

- a July 31, 1991 statute put family benefits up to continental level;

- July 25, 1994 and July 5, 1996 statutes raised other family allowances up to national level;

- a January 1, 1996 decree raised the Minimum Growth Wage (SMIC) up to continental level.

Was "social equality" thus reached? Not yet, as several allowances still remained lower: personalized housing care, family complement, isolated-parent allowance, minimum integration income.

On January 1, 1993, it was done away with the FASSO (Compulsory Health and Social Action Fund), so as beneficiaries would get the full amount of family benefits.

On July 1, 1993, the amount of family benefits is lined up with mainland France; but family complement and allowance for "isolated parent" remain lower. 
On July 25,1994 , was adopted a statute - called "Perben statute", from the name of the minister who drew it up - designed to promote employment, professional integration and economic activities in overseas départements. This statute included two interesting provisions as far as welfare was concerned:

- a national agency named Agence départementale d'insertion was set up in each overseas département, and has to propose public interest jobs to beneficiaries of the Minimum Integration Income (RMI) through Integration Contracts;

- employers hiring long-term job-seekers or Minimum Integration Income beneficiaries were to be exempted from employer's contributions for two years, and to get a $20.000 \mathrm{~F}$ subsidy, through "Access to Job Contracts" including State-financed professional training.

\section{THE IMPACT OF "OVERSEAS ORIENTATION STATUTE"}

The latest important text so far including provisions on welfare is December 13, 2000 "Overseas Orientation Statute". A new step is made toward social equality, on one hand, and new rules are set up to promote employment, on the other hand:

- the amount of Minimum Integration Income will be brought into line with its amount in continental France in a 3-year span of time;

- the value of the isolated parent allowance will be brought into line in a 7-year span of time;

- through an agreement between the Government and the President of the Conseil général (the elected council of the département), beneficiaries of the Minimum Integration Income for two years at least may get a solidarity income if they commit themselves to go out of labor market; 
- a back-to-work allowance is introduced for beneficiaries of Minimum Integration Income, or specific solidarity allowance, or widowhood allowance, or allowance for isolated parents, who intend to set up or buy a business, or to work at customer's home, or are hired by an employer;

- retired workers, workers in early retirement, job-seekers, recipients of a substitute income, may be hired as godfathers to provide professional training to young workers;

- through a "Projet Initiative-Jeune", young people may get a financial support from the State: either an amount of capital, if they intend to open or buy a business, or by installments, to finance a professional training outside their département;

- through a "Congé-solidarité", a 55 years-old (or more) salaried worker may get an allowance if he or she resigns his or her contract of employment and stops working, so as a young worker be hired.

Fifty-five years after the adoption of March 19, 1946 statute, which changed Old colonies into départements, French welfare is nearly totally extended to them. The average standard of life was hugely improved, and poverty eradicated. However, this policy has been laying the grounds of a specific culture - an "assisted society" - that does not pave the way to economic development... 


\section{BIBLIOGRAPHY}

- Blérald A.-Ph., «Le bilan économique et social de la décentralisation: une autre dépendence ? ", in Fortier J.-Cl. (dir.), Questions sur l'administration des DOM, Economica / PUAM, 1989 , pp. 251 et ss.

- Chauchard J.-P., Droit de la Sécurité sociale, LGDJ, 1998

- Dorléans Ch., "Les effets de la protection sociale», lecture delivered at the School of Law and Economics of Martinique, on March 28, 2001

- Douence J.-Cl. :

- «Les départements d'outre-mer», in Encyclopédie «Collectivités locales », Dalloz, p. 1900-1

- «L'exécution des lois dans les départements d'outre-mer. A propos de la décision du Conseil constitutionnel $\mathrm{n}^{\circ} 90-$ 277 DC du 25 juillet $1990 \%$, in Revue française de droit administratif, $1991, \mathrm{n}^{\circ} 2$, p. 345

- Dumont J.-P., Les systèmes de protection sociale en Europe, Economica, 1998, p. 287

- François-Lubin B., «Les méandres de la politique sociale outremer ", in Constant F. et Daniel J. (eds.), 1946-1996. Cinquante ans de départementalisation outre-mer, L'Harmattan, 1997, p. 73

- Huteau G., Sécurité sociale et Politiques sociales, Armand Colin, 2001

- Jos E., «La loi du 19 mars 1946 : une lecture rétrospective », in Marion G.-G. (ed.), Mélanges en hommage à Bernard Vonglis, L'Harmattan, 2000, p. 175

- Kessler F., Droit de la protection sociale, Salloz, Collection «Cours », 2000 
- Lampue P., Droit d'outre-mer et de la coopération, Dalloz, 1969

- Loi n ${ }^{\circ}$ 2000-1207 du 13 décembre 2000 d'orientation pour l'outre-mer, Journal officiel de la République française, 14 décembre 2000, p. 19760

- Miclo F., Le régime législatif des départements d'outre-mer et l'unité de la République, Economica, 1982

- Ripert J., Rapport au Ministre des Départements et Territoires d'outre-mer, La Documentation française, 1990

- Schultz P., «L'interventionnisme économique et social dans les DOM », in Faberon J.-Y, et Auby J.-F. (eds.), L'évolution du statut de département d'outre-mer, Presses universitaires d'AixMarseille, 1999, p. 43

- Ziller J., Les DOM-TOM, LGDJ, 1991, pp. 42 et ss. 


\begin{abstract}
On March 19, 1946, a statute was promulgated in Paris setting up the "Old Colonies" of Guadeloupe, Martinique, Guyane and Réunion in French départements. Members of Parliament elected in these territories had strongly urged French Government to put an end to colonialism not by granting independence but by integrating them thoroughly into the Nation: as colonies were ruled by specific statutes and decrees, départements are all ruled by common statutes and decrees.
\end{abstract}

Members of Parliament who asked for this reform expected French sophisticated welfare system to be extended to these societies, where colonialism had created acute poverty. As a matter of fact, French welfare was, year after year, extended, but not fast enough to avoid some deep frustrations.

\section{RESUME}

La loi du 19 mars 1946 érigeant en départements les « vieilles colonies » qu'étaient la Guadeloupe, la Martinique, la Guyane et la Réunion réalisait, à la demande insistante des parlementaires représentant ces territoires, leur décolonisation non pas par la sécession mais, au contraire, par leur intégration à la Nation. A cet effet, le passage au statut de départements entraînait l'application automatique, en principe, des lois et décrets adoptés à Paris, alors que les colonies sont régies par des textes spécifiques.

Les initiateurs de cette réforme étaient surtout motivés par le désir d'obtenir dans ces territoires profondément marqués par les inégalités sociales coloniales l'application du système de protection sociale perfectionné dont la métropole était en train de se doter. De fait, les dispositifs nationaux furent progressivement étendus à ces populations, mais à un rythme lent qui suscita beaucoup de frustration. 